\title{
Performance of R141b Ejector with Thermal Storage for Solar Air Conditioning
}

\author{
Chakri Sripanom and Sarayooth Vaivudh \\ SERT (School of Renewable Energy Technology), Naresuan University, Phitsanulok 65000, Thailand
}

Received: July 07, 2015 / Accepted: August 05, 2015 / Published: September 30, 2015.

\begin{abstract}
This paper was designed to determine the performance of the R141b ejector includes analysis in economics. The first step is to determine the operating condition and ejector geometry through computer calculation program. That found at the generator temperature $84{ }^{\circ} \mathrm{C}$ and evaporator temperature $8{ }^{\circ} \mathrm{C}$, diameter of nozzle throat is $2 \mathrm{~mm}$, diameter of nozzle exit is $8 \mathrm{~mm}$, diameter of mixing chamber inlet is $25 \mathrm{~mm}$, diameter of constant area section is $8 \mathrm{~mm}$. Area of evacuated solar collector is $10 \mathrm{~m}^{2}$, thermal storage tank size is $0.33 \mathrm{~m}^{3}$, cold thermal storage size is $2.3 \mathrm{~m}^{3}$. The entrainment ratio and COP (coefficient of performance) of computer calculation program are 0.295 and 0.235 , respectively. The second step ejector is fabricated and equipped to solar ejector refrigeration system, it is found that, average COP is 0.265 . The economics analysis of solar ejector cooling system are invested in the investment cost was 158,158 baht. When calculating payback period was 7.73 years, the return value on a NPV (net present value) was $60,872.63$ baht of lifetime of the system throughout a period of 15 years, and IRR (internal rate of return) is $13.57 \%$.
\end{abstract}

Key words: Solar energy, ejector, energy storage system.

\section{Introduction}

Currently, global warming has been causing an increase in global temperature. As a result, there has been an increase in air conditioning demand as well, which can be observed from the worldwide growth of air conditioning market. The growth rate assessment is at about $17 \%$ [1]. Approximately $15 \%$ of electronic products worldwide are mostly air conditioning and refrigeration systems [2]. In Thailand, electricity consumption can be categorized into three main parts: $40 \%$ consumed by industry sector, $35 \%$ consumed by business sector, and 25\% consumed by residential sector. Over $50 \%$ (approximately $50 \times 10^{3} \mathrm{GWh} /$ year) of electricity cost is consumed by air conditioning systems. Electronic productions from power plant thusly have to support the air conditioning system at about $600 \mathrm{MW}$ each year [3]. The common cooling technologies being used are vapor compressed refrigeration systems that are made to be compatible

Corresponding author: Chakri Sripanom, research field: renewable energy. E-mail: chakri.sripanom@gmail.com. with solar energy in order to extract electricity from solar cells, which are desiccant system, passive cooling system, absorption refrigeration system, and ejector refrigeration system. According to literature review conducted by many researchers, an ejector refrigeration system has been studied and developed due to many of its advantages, for example, the simplicity of the installation, design and operation, the relatively low cost in heat operation system, the possible usage in residential sector, and it can be used as an environment-friendly refrigerator as well. However, the ejector refrigeration system is prone to be lacking in energy storage system.

This present study will design ejector refrigeration system using R141b as refrigerant. Designed parameters which are obtained from program for fabricating the system are such as condenser pressure and temperature, optimal mass flow rate of entrained fluid, load required at condenser, generator and evaporator, ejector performance and COP (coefficient of performance). This work is to develop a residential 
solar ejector refrigeration system with an energy storage system for air conditioning - the performance analysis and economic feasibility.

\section{System Design}

\subsection{Ejector Design}

Fig. 1 [4] shows geometry and sections of ejector, they are consist of three main parts: a suction chamber, a constant area and mixing chamber and a diffuser.

When the primary flow goes through a converging-diverging nozzle in the ejector, vapor is drawn from the evaporator. The secondary flow is accelerated to a high velocity vapor stream and reaches subsonic velocity. Mixing starts at the onset of the constant-area section (section y-y, hypothetical throat (Fig. 1)). In section y-y, both streams develop uniform pressure; choking of the secondary flow occurs. A combined stream develops into a transient supersonic stream and shocks at section s-s. The velocity of the mixing fluid must be high enough to increase the pressure after deceleration in the diffuser to a suitable condensing pressure.

Computer calculation program of ejector refrigeration system has been developed to obtain parameters which are used to design and fabricate the refrigeration system. The flow chart of simulation can be expressed as Fig. 2, and assumption for computer simulation program as efficiency of nozzle $\left(\eta_{N}\right)$ is 0.85 , efficiency of suction $\left(\eta_{N e}\right)$ is 0.85 , efficiency of diffuser $\left(\eta_{D}\right)$ is 0.85 [5], generator temperature $\left(T_{g}\right)$ is $84{ }^{\circ} \mathrm{C}$, condenser temperature $\left(T_{c}\right)$ is $28^{\circ} \mathrm{C}$, evaporator temperature $\left(T_{e}\right)$ is $8{ }^{\circ} \mathrm{C}$, specific heat of $\mathrm{R} 141 \mathrm{~b}$ at $25^{\circ} \mathrm{C}$ $\left(C_{p}\right)$ is $1.16 \mathrm{~kJ} /(\mathrm{kg} \cdot \mathrm{K})$.

\subsection{Evacuated Tube Solar Collector}

A solar system unit is used to supply the heat to the generator as a major source of energy for the ejector cooling system. Hot water is used in this research generate from evacuated tube solar collector. Evacuated tube collectors use liquid-vapor phase change materials

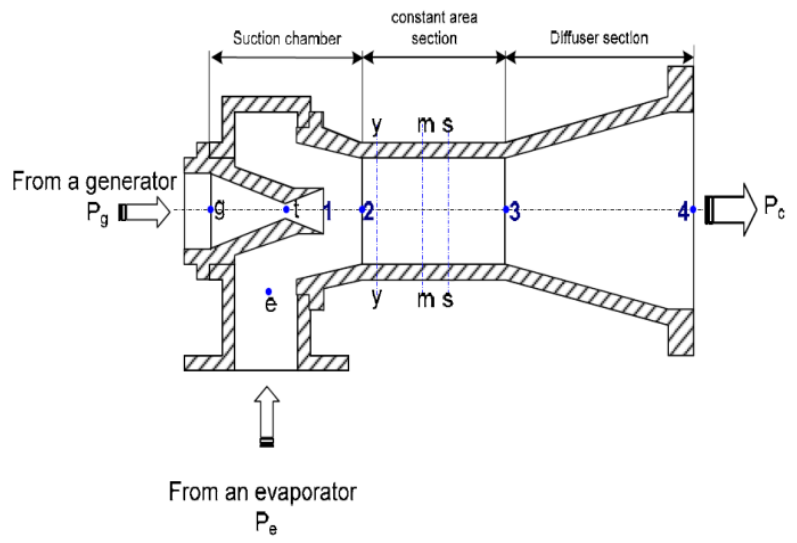

Fig. 1 Ejector geometry and sections.

to transfer heat at high efficiency. The useful energy collected from a collector can be obtained from Eq. (1):

$$
Q_{u}=A_{s c}\left[G_{T} \tau \alpha-U_{L}\left(T_{P}-T_{a}\right)\right]=\dot{m} C_{p}\left(T_{0}-T_{i}\right)
$$

It is defined that, the solar collector efficiency is the ratio of the useful heat gained over any time period to the incident solar radiation over the same period. The instantaneous energy efficiency of the solar collector can also be expressed in the form of the average Bliss coefficient $\left(F_{R} \tau \alpha=0.80\right)$ and the heat loss coefficient $\left(F_{R} U_{L}=1.5\right)[4]$ in Eq. (2):

$$
\eta_{s c}=\frac{Q_{u}}{A_{s c} G_{T}}=F_{R}(\tau \alpha)-\frac{F_{R} U_{L}\left(T_{i}-T_{a}\right)}{G_{T}}
$$

\subsection{Energy Storage System}

The most widely used method of sensible heat storage is a well-mixed liquid storage. The transient energy balance equation for a hot liquid storage tank can be considerably simplified if the temperature in the storage tank is assumed to be uniform, which is called well-mixed storage.

Assuming that, the storage tank has a uniform temperature $T_{s}$, energy balance on a storage tank can then be expressed as:

$$
\left(M C_{p}\right)_{s} \frac{\mathrm{d} T_{s}}{\mathrm{~d} t}=Q_{c}-Q_{L}-(U A)_{s}\left(T_{s}-T_{a}\right)
$$

where, $M$ is the mass of media in storage tank, $Q_{c}$ is the rate of heat addition by the collector, $Q_{L}$ is the rate of heat removal by the load, $U$ is the overall heat transfer collection between media in the tank, $T_{a}$ is the 


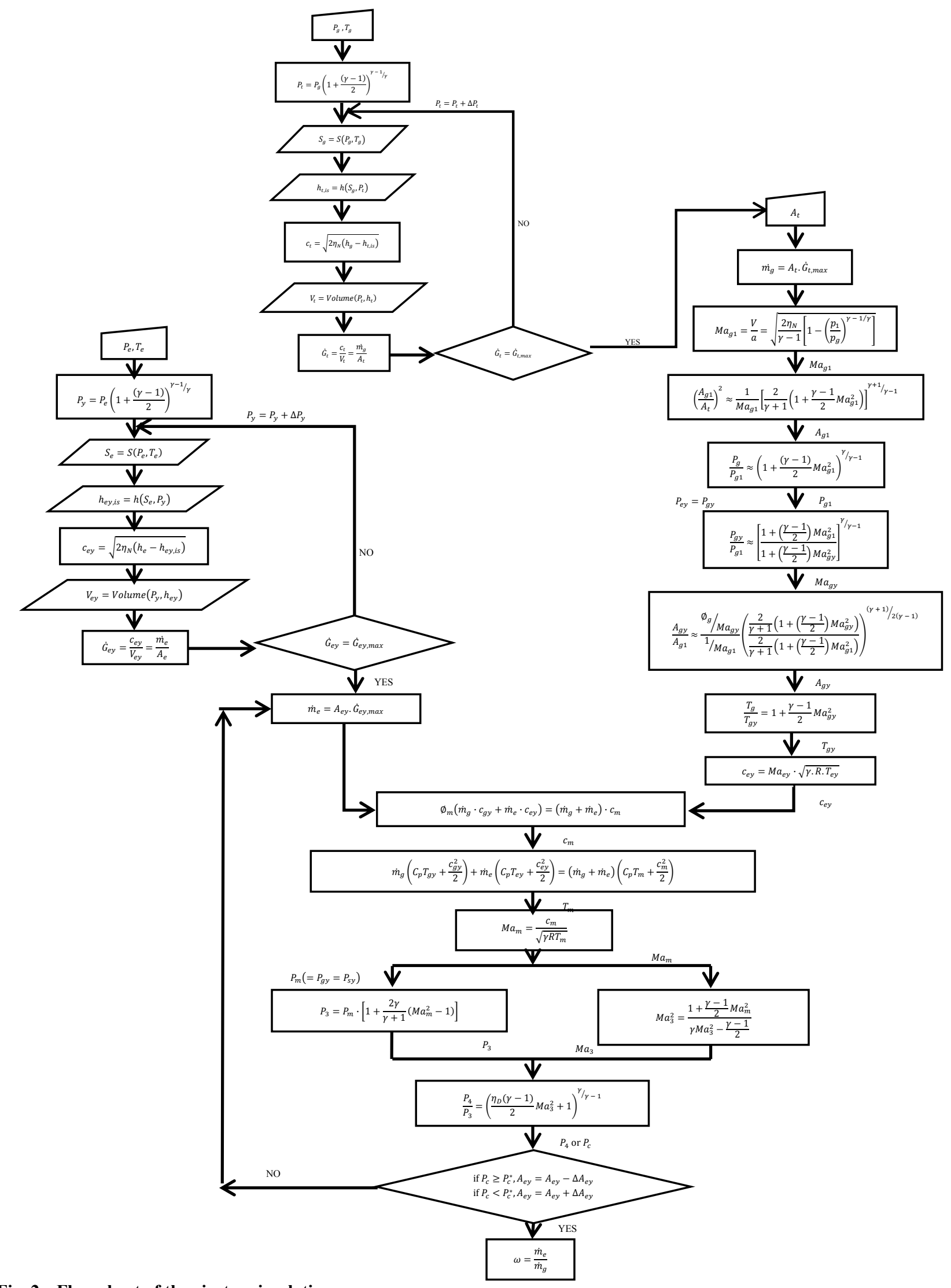

Fig. 2 Flow chart of the ejector simulation. 
ambient at temperature, and $A$ is the surface area of the storage tank.

For a reasonable time period $\Delta t$, the rates of heat additional and removal are assumed to be constant, can be written for each time interval as:

$$
\begin{gathered}
T_{s, \text { new }}=T_{s, \text { old }}+ \\
\frac{\Delta t}{\left(M C_{p}\right)_{s}}\left[Q_{c}-Q_{L}-(U A)_{s}\left(T_{s, \text { old }}-T_{a}\right)\right]
\end{gathered}
$$

\subsection{Performance of Ejector Refrigeration System}

The performance of ejector refrigeration system can be expressed in term of coefficient of performance $C O P_{e j c}$ is defined as the heat flow rate of evaporator $\dot{Q}_{e}$ and generator $\dot{Q}_{g}$ in Eq. (5):

$$
C O P_{e j c}=\frac{\dot{Q}_{e}}{\dot{Q}_{g}}
$$

Terms of $\dot{Q}_{e}$ and $\dot{Q}_{g}$ can be expressed in form of enthalpy difference and system performance is also written as:

$$
C O P_{e j c}=\omega \frac{h_{e}-h_{c}}{h_{g}-h_{c}}
$$

Ejector performance is measured by the entrainment ratio, which is defined as mass flow ratio of secondary flow to primary flow:

$$
\omega=\frac{\dot{m}_{e}}{\dot{m}_{g}}
$$

\section{Experimental Investigation of Solar Ejector Refrigeration System}

The experimental practice of the R141b ejector refrigeration system uses the operating condition and ejector geometry via the result of the simulation program. The experiment was tested from 9:00 a.m. to 16:00 p.m. at the School of Renewable Energy Technology, Naresuan University, Thailand. Fig. 3 shows a schematic diagram of system. The evacuated tube solar collector provided hot water in to storage tank before start the test, water temperature increase effect from solar radiation which shown in Fig. 4. After that, turn on the hot water pump for it to circulate to the generator to exchange with R141b. Then, turn on the water pump by opening cooling water valve to let water flow through the condenser.

After the R141b is increased to the set point, the vapor enters to the primary nozzle of the ejector by opening the balancing valve manually when the $\mathrm{R} 141 \mathrm{~b}$ vapor reaches the temperature of $84{ }^{\circ} \mathrm{C}$, pressure at 4-5.5 bars. After that, the temperature of generator is steady, by opening balancing valve, the secondary flow is entrained to ejector suction and mixed with the primary flow at mixing chamber. In order to continuously make the system operate, the

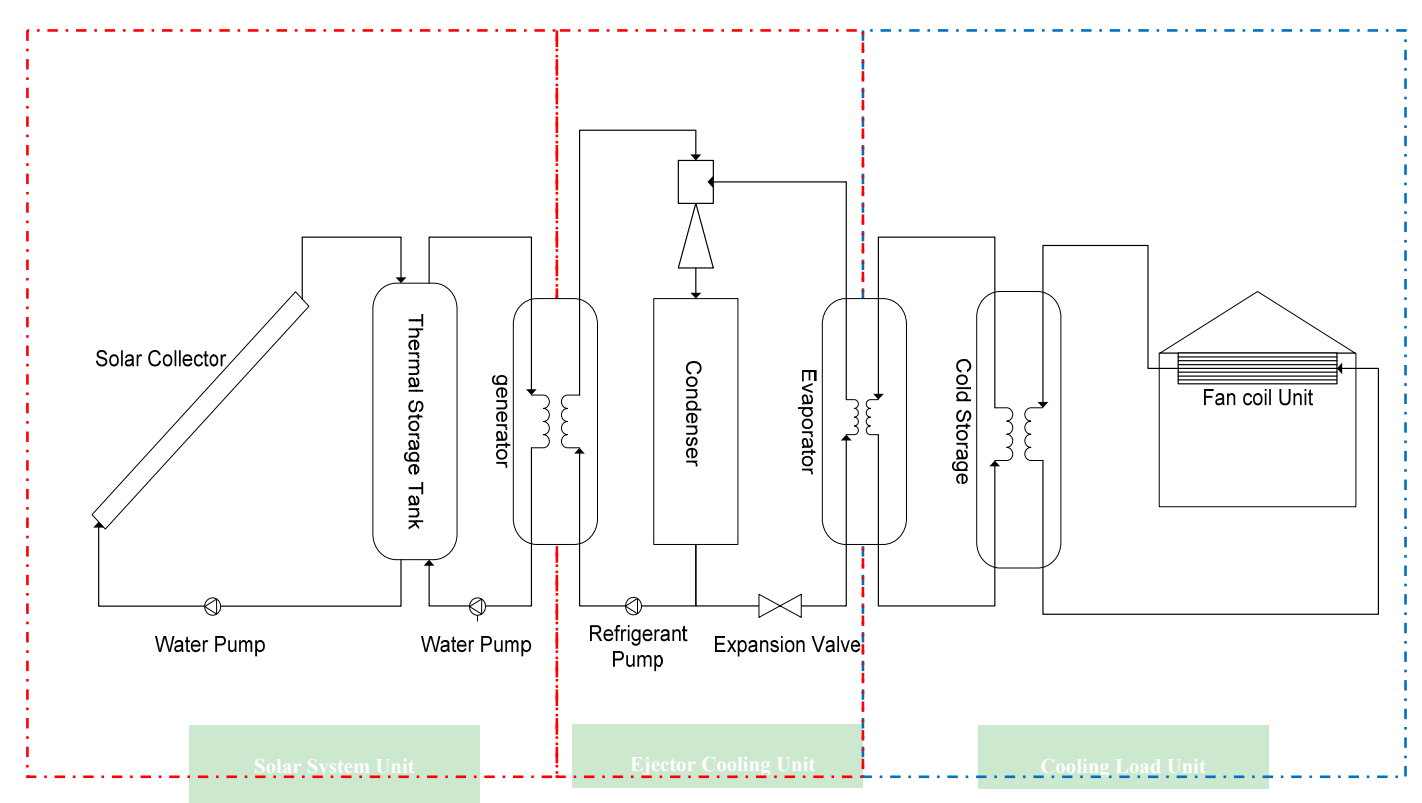

Fig. 3 Schematic diagram of system. 


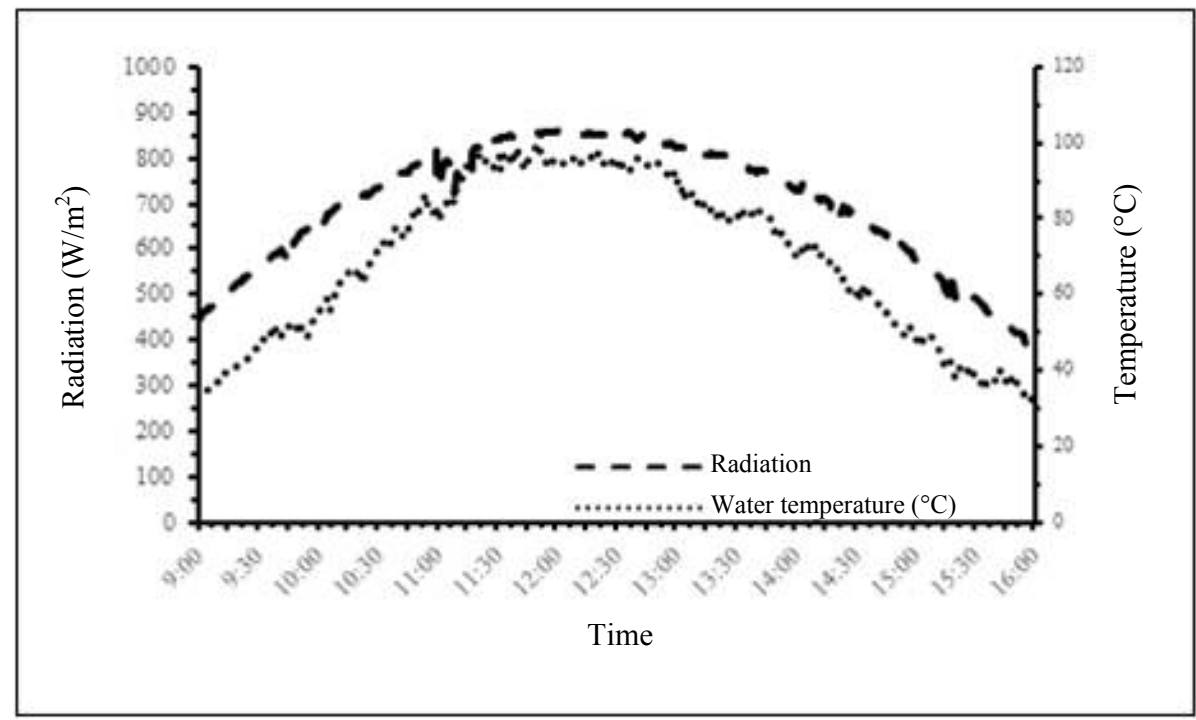

Fig. 4 Temperature of water at various times with radiation.

refrigeration pump should be turned on to feed the refrigerant from the receiver tank to the generator.

Storage tank, the temperature output from collector must be higher than $80^{\circ} \mathrm{C}$, given collector efficiency is 0.5 approximately, solar radiation is $715 \mathrm{~W} / \mathrm{m}^{2}$.

\section{Results and Discussion}

The result of the ejector geometry is calculated as follows. Nozzle throat diameter is $2 \mathrm{~mm}$, nozzle inlet diameter is $7.75 \mathrm{~mm}$, nozzle exit diameter is $8 \mathrm{~mm}$, mixing chamber inlet diameter is $25 \mathrm{~mm}$, mixing chamber outlet diameter is $8 \mathrm{~mm}$, diffuser outlet diameter is $17.8 \mathrm{~mm}$, mixing chamber length is $25 \mathrm{~mm}$, diffuser chamber length is $56 \mathrm{~mm}$. Calculated the mass flow rate is $0.0152 \mathrm{~kg} / \mathrm{s}$, solar collector area of $10 \mathrm{~m}^{2}$ for heated water $328.13 \mathrm{~kg}$ in the $0.33 \mathrm{~m}^{3}$, for supply the hot water from storage tank to ejector cooling system, to produce the chilled water $8-10^{\circ} \mathrm{C}$, stored to cold thermal storage, for provide chilled water to air condition, in this case, flow rate is $0.104 \mathrm{~kg} / \mathrm{s}$, remove heat from water of $2,257 \mathrm{~kg}$ in the $2.3 \mathrm{~m}^{3}$ for $6 \mathrm{~h}$ at $25^{\circ} \mathrm{C}$. For cooling system capacity is $3.5 \mathrm{~kW}$.

In case constant evaporator temperature and varied generator temperature range from $80{ }^{\circ} \mathrm{C}$ to $90{ }^{\circ} \mathrm{C}$, the mass flow rate of primary fluid is increase $0.0051 \mathrm{~kg} / \mathrm{s}$ to $0.0064 \mathrm{~kg} / \mathrm{s}$, while mass flow rate of secondary fluid is $0.0016 \mathrm{~kg} / \mathrm{s}$, since it is lead cause to reduce the entrainment ratio and COP.

In addition to high generator, temperature leads to higher angle of expansion of primary fluid from primary nozzle. Found increase generator temperature, the saturated vapor primary will spread and obstruct the secondary fluid is entrained to mixing chamber section. This reason to entrainment ratio and COP is decrease. That is shown in Fig. 5.

The experimental study varied generator temperature range from $80{ }^{\circ} \mathrm{C}$ to $90{ }^{\circ} \mathrm{C}$, constant evaporator temperature. Entrainment ratio and COP was decreased. As shown in Fig. 5, the mass flow rate of primary fluid is $0.0233 \mathrm{~kg} / \mathrm{s}$, mass flow rate of secondary fluid is decrease from $0.0043 \mathrm{~kg} / \mathrm{s}$ to $0.0029 \mathrm{~kg} / \mathrm{s}$.

The comparisons COP of design result and experimental result, as shown in Fig. 6, trend graph is similar. Found increase generator temperature, entrainment ratio and COP is decrease. Because of the saturated vapor primary will spread and obstruct, the secondary fluid is entrained to mixing chamber section. The system performance was shown and compared the results with experimental result. The deviation of COP has average $0.182 \%$.

The relationship among temperature of condenser evaporator and chilled water, with time, from Fig. 7, it can be seen that, evaporator and chilled water temperature curve give the same trend. Evaporator and 


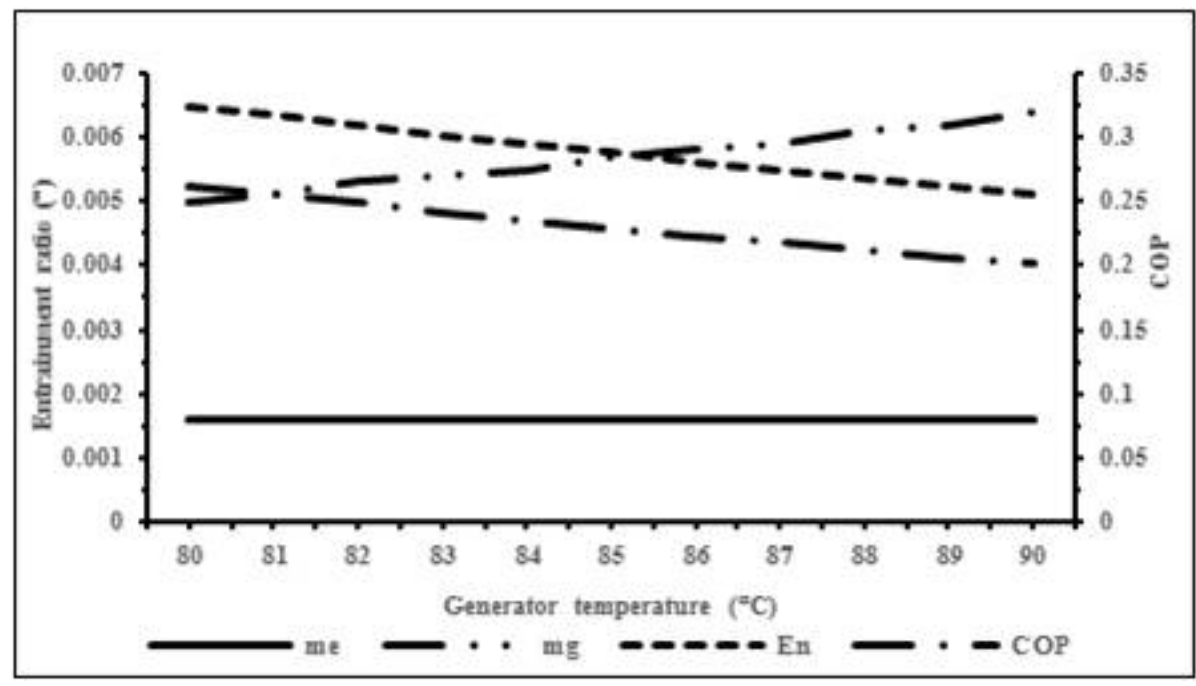

Fig. 5 Relationships of the COP, entrainment ratio and mass flow rate with the generator temperature from design result.

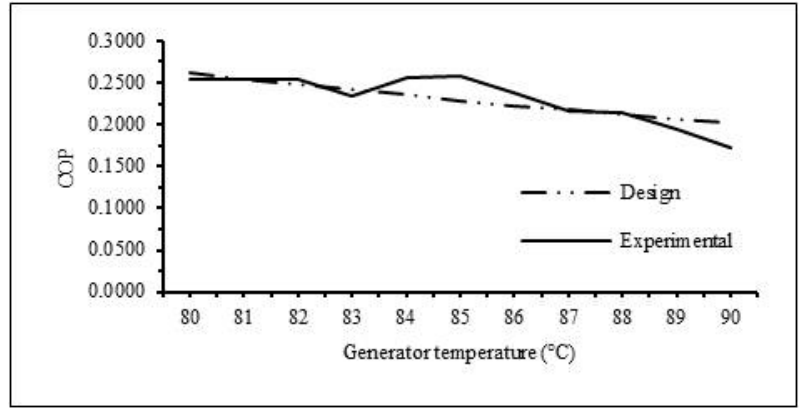

Fig. 6 Comparison of the performance results of design and experimental with the generator temperature.

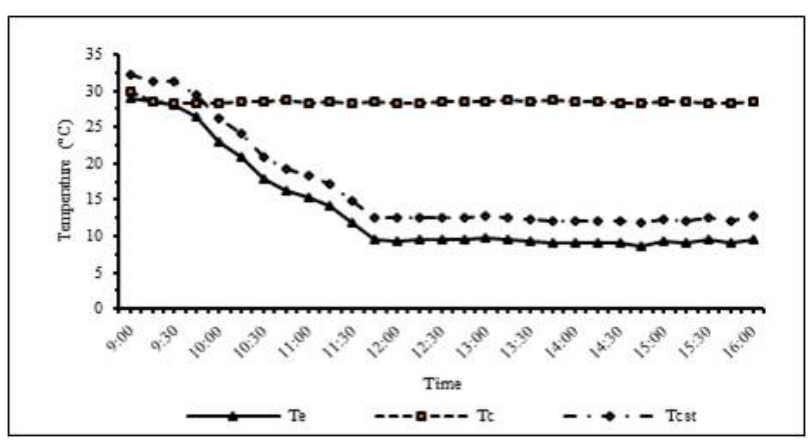

Fig. 7 Temperature of condenser, evaporator and chilled water in storage tank.

chilled water temperatures are lowest at $9{ }^{\circ} \mathrm{C}$ and $12{ }^{\circ} \mathrm{C}$, respectively. Allouche, et al. [6] studied the change of evaporator temperature by predicting from CFD (computational fluid dynamics) program which the results are similar to this research.

The average COP obtained is 0.265 and the refrigeration system performance yields the highest COP of 0.301 at 11:15 a.m., and COP reduces to be
0.277 at 16:00 p.m.. That is shown in Fig. 8, the change of COP can be explained as the change in evaporator temperature. COP is higher in the first period as higher evaporator temperature and COP is decrease as lower evaporator temperature at longer time. This result is given the same as Pollerberg, et al. [7] and Yen, et al. [8] Furthermore, the results show condenser temperature significantly affects COP as well. That is, as condenser temperature decreases, COP increases which this result is similar to Petrenko, et al. [9] and Pollerberg, et al. [7].

\subsection{Economic Analysis}

The economics of solar energy systems are particularly complex with many inevitable uncertainties due to several factors. The principal reason to use the solar energy for heating or cooling is the cost reduction. Therefore, an economic analysis must be carried

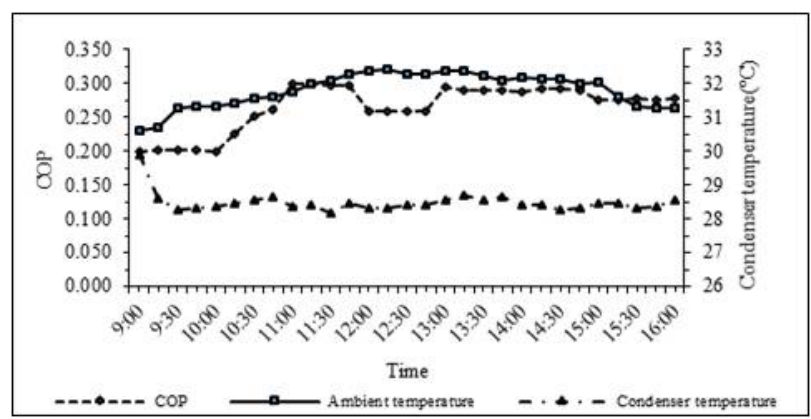

Fig. 8 The COP of system, ambient temperature and condenser temperature at the various times. 
out to determine whether a particular solar system is economically advantageous for a particular project.

The solar ejector cooling system is invested in the investment cost 158,158 baht. Loaning interest rate $8.7 \%$ [10], when calculating payback period is 7.73 years. The return value on a NPV (net present value) is $60,872.63$ baht of lifetime of the system throughout a period of 15 years, and IRR (internal rate of return) is $13.57 \%$.

\section{Conclusions}

Solar ejector refrigeration system has been designed and experimentally fabricated. Computer program of $\mathrm{R} 141 \mathrm{~b}$ developed to study effect of operating condition and ejector geometry on ejector performance and COP. From testing results of solar ejector refrigeration system, that found, entrainments ratio, average COP and chilled water temperature are $0.295,0.265$ and $10{ }^{\circ} \mathrm{C}$, respectively. Thermal storage tank size is $0.33 \mathrm{~m}^{3}$, cold thermal storage tank size is $2.5 \mathrm{~m}^{3}$, solar collector area is $10 \mathrm{~m}^{2}$, and economics analysis of invested in the investment cost is 158,158 baht, payback period is 7.73 years. The return value on a NPV is $60,872.63$ baht of lifetime of the system throughout a period of 15 years, and IRR is $13.57 \%$.

\section{References}

[1] Henning, H. M. 2007. "Solar Air-Conditioning and Refrigeration." Task 38 of the IEA (International Energy Agency) Solar Heating and Cooling Programme. Accessed May $\quad 2011$. http://lmora.free.fr/task38/pdf/matin/Henning.pdf.
[2] Chunnanond, K., and Aphornratana, S. 2004. "Ejectors: Applications in Refrigeration Technology." Renewable and Sustainable Energy Reviews 8 (2): 129-55.

[3] Sun, D. W., and Eames, I. W. 1996. "Performance Characteristics of HCFC-123 Ejector Refrigeration Cycles." International Journal of Energy Research 20 (10): 871-85.

[4] Pridasawas, W. 2006. "Solar-Driven Refrigeration System with Focus on the Ejector Cycle." Ph.D. thesis, KTH (Kungliga Tekniska Högskolan).

[5] Huang, B. J., Chang, J. M., Wang, C. P., and Petrenko, V. A. 1999. "A 1-D Analysis of Ejector Performance." International Journal of Refrigeration 22 (5): 354-64.

[6] Allouche, Y., Bouden, C., and Varga, S. 2014. "A CFD Analysis of the Flow Structure inside a Steam Ejector to Identify the Suitable Experimental Operating Conditions for a Solar-Driven Refrigeration System." International Journal of Refrigeration 39 (March): 186-95.

[7] Pollerberg, C., Heinzel, A., and Weidner, E. 2009. "Model of Solar Driven Steam Jet Ejector Chiller and Investigation of Its Dynamic Operational Behavior." Solar Energy 83 (5): 732-42.

[8] Yen, R. H., Huang, B. J., Chen, C. Y., Shiu, T. Y., Cheng, C. W., Chen, S. S., and Shestopalov, K. 2013. "Performance Optimization for a Variable Throat Ejector in a Solar Refrigeration System." International Journal of Refrigeration 36 (5): 1512-20.

[9] Petrenko, V. O., Huang, B. J., and Shestopalov, K. O. 2011. "Innovative Solar and Waste Heat Driven Ejector Air Conditioner and Chiller." In Proceedings of the 2011 2nd International Conference on Environmental Science and Technology IPCBEE (International Proceedings of Chemical, Biological and Environmental Engineering), (V1-338)-(V1-343).

[10] Bank of Thailand. "Loan Rates of Commercial Banks as of 19 May." Bank of Thailand. Accessed May 19, 2015. https://www.bot.or.th/thai/statistics/_layouts/application/i nterest_rate/in_rate.aspx. 